\section{To: (Receiving Organization) \\ Distribution}

5. Proj./Prog./Dept./Div.:

Project $W-420$

8. Originator Remarks:

Attached is the Year 2000 Compliance Assessment for Project W-420.

11. Receiver Remarks: 11A. Design Baseline Document? [] Yes [X] No
3. From: (Originating Organization) $83100 /$ TWRS Upgrades

6. Design Authority/ Design Agent/Cog. Engr.: JH Bussel1
4. Related EDT No.:

$\mathrm{N} / \mathrm{A}$
7. Purchase Order No.:

$\mathrm{N} / \mathrm{A}$

9. Equip./Component No.:

$\mathrm{N} / \mathrm{A}$

10. System/Bldg./Facility: Year 2000/241-G

12. Major Assm. Dwg. No.:

N/A

13. Permit/Permit Application No.: N/A

14. Required Response Date: $\mathrm{N} / \mathrm{A}$



\begin{tabular}{|c|c|c|c|}
\hline 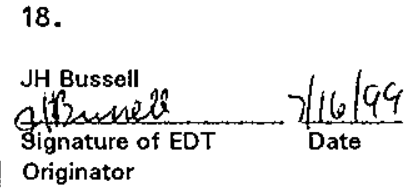 & 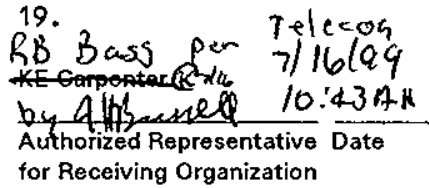 & $\underset{\substack{\text { Design Authority } \\
\text { Cognizant Manager }}}{20 .} \frac{7 / 16 / 99}{\text { Date }}$ & $\begin{array}{l}\text { 21. DOE APPROVAL (if required) } \\
\text { Ctrl. No. } \\
\text { [I Approved } \\
\text { I] Approved } w / \text { comments } \\
\text { [] Disapproved } w / \text { comments }\end{array}$ \\
\hline
\end{tabular}




\title{
PROJECT W-420 VENTILATION STACK MONITORING SYSTEM YEAR 2000 COMPLIANCE ASSESSMENT PROJECT PLAN
}

J. H. Bussell

Numetec

Richland, WA 99352

U.S. Department of Energy Contract DE-AC06-96RL13200

\author{
EDT/ECN: 626714 \\ UC: 2030 \\ Org Code: 83100 \\ B\&R Code: EW02J123 \\ Charge Code: $106597 \dot{A} J 10$ \\ Total Pages: 9
}

Key Words: Year 2000, Y2K, Project W-420

Abstract:

This document contains a limited assessment of Year 2000 compliance for Project $w-420$. Additional information is provided as a road map to project documents and other references that may be used to verify Year 2000 compliance.

TRADEMARK DISCLAIMER. Reference herein to any specific commercial product, process, or service by trade name, trademark, manufacturer, or otherwise, does not necessarily constitute or imply its endorsement, recommendation, or favoring by the United States Government or any agency thereof or its contractors or subcontractors.

Printed in the United States of America. To obtain copies of this document, contact: Document Control Services, P.O. Box 950, Mailstop H6-08, Richland WA 99352, Phone (509) 372-2420; Fax (509) 376-4989.

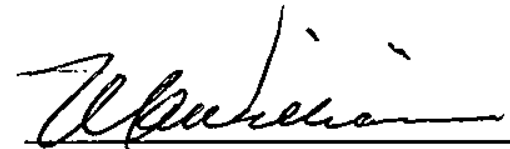

Release Approval

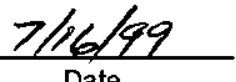

Date

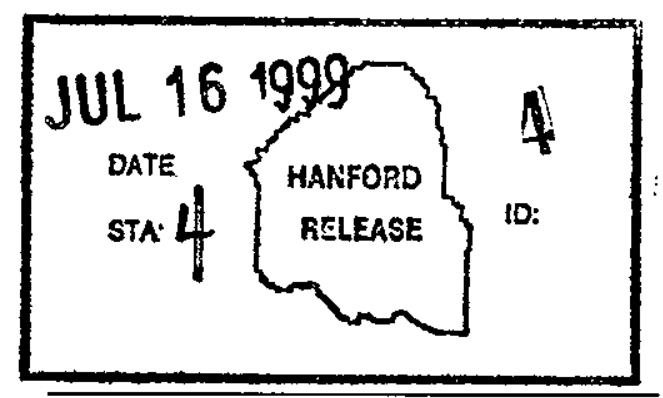

Release Stamp 


\title{
PROJECT $\mathbf{W}-420$
}

\section{VENTILATION STACK MONITORING SYSTEM UPGRADES \\ YEAR 2000 COMPLIANCE ASSESSMENT PROJECT PLAN}

\author{
Prepared by: \\ J. H. Bussell \\ NUMATEC HANFORD CO.
}

July 13, 1999 


\section{TABLE OF CONTENTS}

1.0 SCOPE

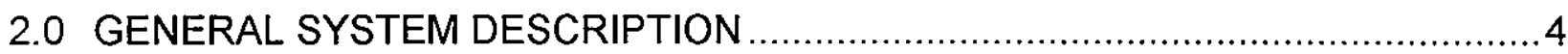

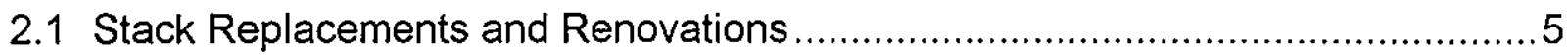

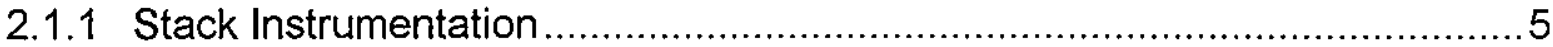

2.1.2 Stack Sampling Probes ........................................................................ 5

2.1.3 Stack Sample Probe Inspection and Flow Measurement Ports ...................6

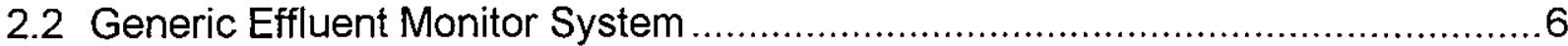

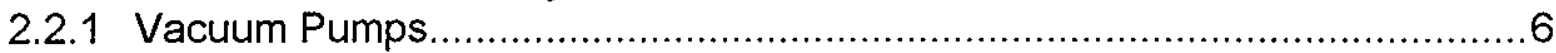

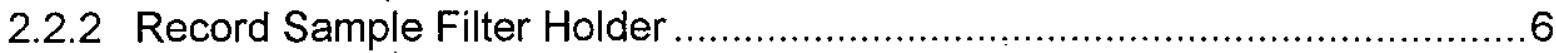

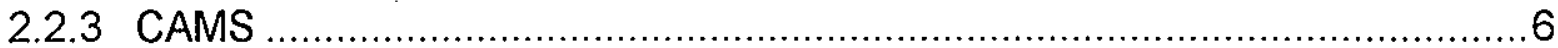

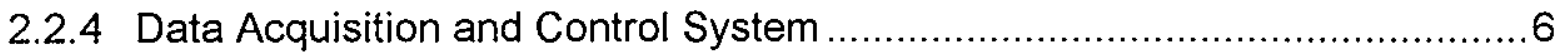

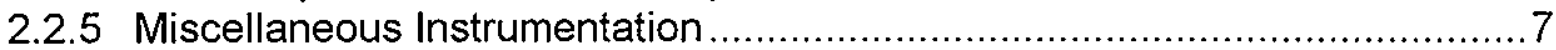

3.0 ASSESSMENT OF YEAR 2000 (Y2K) COMPLIANCE …..............................

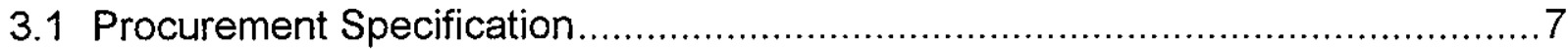

3.2 System Dates and Date Related Functions ................................................ 7

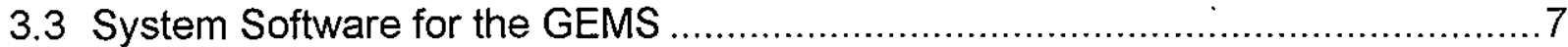

3.4 Year 2000 (Y2K) Compliance of the PLC ..................................................

3.5 Year 2000 (Y2K) Compliance of the Supplementary Computer ..........................7

3.6 Year 2000 (Y2K) Compliance of the Alpha and Beta CAMs ............................... 8

3.7 Year 2000 (Y2K) Compliance of Miscellaneous Instrumentation......................... 8

3.8 Assessment of Potential Year 2000 (Y2K) Problems ....................................... 8

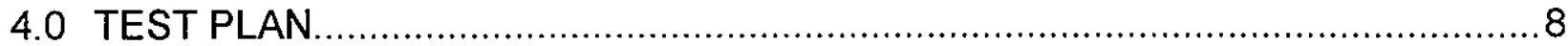

5.0 YEAR 2000 (Y2K) ACTIVITIES, MAJOR MILESTONES, AND DELIVERABLES ....8

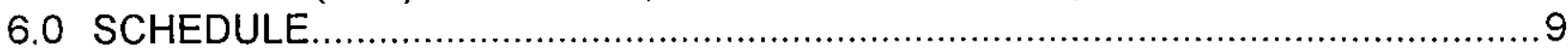

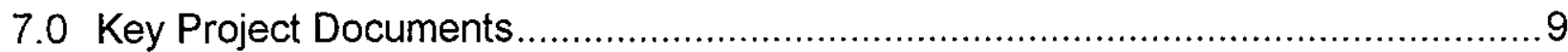




\subsection{SCOPE}

This assessment describes the potential Year 2000 (Y2K) problems and describes the methods for achieving Y2K Compliance for Project W-420, Ventilation Stack Monitoring Systems Upgrades. The purpose of this assessment is to give an overview of the project. This document will not be updated and any dates contained in this document are estimates and may change. The project work scope includes upgrades to ventilation stacks and generic effluent monitoring systems (GEMS) at the 244-A Double Contained Receiver Tank (DCRT), the 244-BX DCRT, the 244-CR Vault, tanks 241-C105 and 241-C-106, the 244-S DCRT, and the 244-TX DCRT.

A detailed description of system dates, functions, interfaces, potential $\mathrm{Y} 2 \mathrm{~K}$ problems, and date resolutions can not be described since the project is in the definitive design phase. This assessment will describe the methods, protocols, and practices to ensure that equipment and systems do not have Y2K problems.

\subsection{GENERAL SYSTEM DESCRIPTION}

Project W-420 will upgrade six 200-Area Tank Farm stacks to meet the National Emission Standards for Hazardous Air Pollutants (NESHAPS), Title 40, CFR, Part 61 Subpart $H$, requirements. Project $W-420$ will be renovating or replacing stacks and will be installing new GEMS as shown below in Table 1.

Table 1 Scope of Project W-420

\begin{tabular}{|c|l|l|l|l|}
\hline & Facility & Stack Number & $\begin{array}{l}\text { Stack } \\
\text { Modification }\end{array}$ & $\begin{array}{l}\text { Generic } \\
\text { Effluent } \\
\text { Monitoring } \\
\text { System } \\
\text { (GEMS) }\end{array}$ \\
\hline 1 & $244-$-A DCRT and Annulus & $296-$ A-25 & Replacement & New System \\
\hline 2 & $\begin{array}{l}244-B X \text { DCRT and } \\
\text { Annulus }\end{array}$ & $296-B-28$ & Replacement & New System \\
\hline 3 & $244-C R$ Vault & $296-C-05$ & Modification & New System \\
\hline 4 & $\begin{array}{l}241-C-105 \text { and 241-C-106 } \\
\text { Primary. Tank } \\
\text { Ventilation }\end{array}$ & $296-$ P-16 & Replacement & New System \\
\hline 5 & 244-S DCRT and Annulus & $296-S-22$ & Replacement & New System \\
\hline 6 & $\begin{array}{l}244-T X \text { DCRT and } \\
\text { Annulus }\end{array}$ & $296-T-18$ & Replacement & New System \\
\hline
\end{tabular}


These facilities are described as follows:

Four Double Contained Receiver Tanks (DCRTs), which are small (approximately 16,300 to 31,000 gal, or 62 to $117 \mathrm{~m}^{3}$ ) tanks used for transferring liquid radioactive wastes. These facilities are designated as 244-A, 244-BX, 244-S, and 244-TX. They are normally maintained in an empty state (except for the non-pumpable heel) when a transfer is in progress. These DCRTs will be used for saltwell pumping through 1999 and may be used for waste retrieval through 2024. Upgrades to their stack monitoring systems will support these missions.

- The 244-CR Vault is now used primarily as a double contained receiver tank (DCRT) for transferring liquid radioactive wastes from the 241-C Tank Farm. There are four tanks in the vault, of which two are isolated and inactive, and one is used as a drain tank. The fourth is a 15,000 -gal $\left(57 \mathrm{~m}^{3}\right)$ tank that is in active service. The 244-CR Vault will be used to support saltwell pumping through 1999 and may be used for waste retrieval through 2018. Upgrading the stack monitoring system will support this mission.

The $\mathrm{P}-16$ exhauster is used to maintain the waste temperature in Tanks C-105 and C-106 within TSR limits. In 1999, Tank C-106 will have a separate exhauster installed and the waste will be partially retrieved, decreasing the heat load in the tank. The P-16 exhauster will remain in service indefinitely as a backup ventilation system. Upgrading the stack monitoring system will support this mission.

The basic intent of the upgrades is to replace existing stack monitoring systems with systems that are fully compliant with current regulatory and authorization basis (AB) requirements, and to preserve any existing facility or equipment functions that may be affected in the process.

\subsection{Stack Replacements and Renovations}

Ventilation exhaust stack being replaced or renovated are circular ducts and consist of three different diameters, 6 inches, 16 inches, and 18 inches. The height of the stacks range from 12 to 60 feet.

\subsubsection{Stack Instrumentation}

Stack instrumentation will consist of a flow measurement element and an associated flow measurement transmitter, a stack pressure transmitter, a stack temperature element and an associated temperature transmitter.

\subsubsection{Stack Sampling Probes}

A sampling probe will be installed in each stack to provide an air sample stream for a record sample filter and a sampling probe will also be installed in each stack to provide air sample stream to alpha and/or beta continuous air monitors (CAMs). 


\subsubsection{Stack Sample Probe Inspection and Flow Measurement Ports} Inspection ports and measurement ports will be installed in each stack to permit inspection of the sample probes and to permit manual flow measurements. The inspection ports are 2-inch or 3-inch capped openings in the side of the stack. The measurement ports are $3 / 4$-inch or 1 -inch capped openings. Manual stack flow measurements are done on a periodic basis to validate the stack flow instrumentation.

\subsection{Generic Effluent Monitor System}

The Generic Effluent Monitor consists of five parts:

(1) Vacuum Pumps to draw air samples from the stack through a record sample filter and the CAMs

(2) A Record Sample Filter Holder

(3) Alpha and/or Beta CAMs to provide warning of airborne radioactive contamination and to provide a signal to shut down the facilities ventilation system

(4) Data Acquisition and Control System

(5) Miscellaneous Instrumentation such as flow controllers for each sample stream, e.g. record sample filter holder

\subsubsection{Vacuum Pumps}

Two vacuum pumps will be provided in the GEMS. One of the vacuum pumps will be operating while the other vacuum pump will be in reserve. The reserve vacuum pump will start on failure of the operating pump. The control system will detect the loss of the vacuum and initiate the startup of the reserve vacuum pump.

\subsubsection{Record Sample Filter Holder}

The record sample filter holder will hold a 47-mm diameter filter and will have provisions for an lodine collection cartridge (activated charcoal or silver zeolite). The record sample filter is changed on periodic basis to comply with regulatory requirements.

\subsubsection{CAMS}

A beta CAM will be provided for each GEMS and an alpha CAM will be installed in locations where alpha contamination is a concern. An Eberline AMS $4^{\circledR}$ has been selected and qualified for use as the beta CAM and an Eberline ALPHA-6A ${ }^{\otimes}$ has been selected and qualified for use as the alpha CAM.

\subsubsection{Data Acquisition and Control System}

The data acquisition and control system will consist of an Allen Bradley ${ }^{\circledR}$ programmable logic controller (PLC) from the SLC-500 ${ }^{\circledR}$ family. An additional computer may be used for data storage. A provision for a future interface with TMACS will be provided but connection to TMACS is not within the scope of Project $W-420$. Alarm relay outputs will be provided for alarm annunciation purposes and for other interlock purposes. 


\subsubsection{Miscellaneous Instrumentation}

Flow controllers will be provided for each sampled stream, e.g. the record sample filter holder and each of the CAMs. Other temperature measurements and differential pressure measurement points are located in the GEMS cabinets.

\subsection{ASSESSMENT OF YEAR 2000 (Y2K) COMPLIANCE}

\subsection{Procurement Specification}

A detailed procurement specification was prepared for the GEMS (Bussell, 1998).

Section 4.1 in the procurement specification requires the Seller to provide a Y2K compliant system. The specification also requires the Seller to provide $\mathrm{Y} 2 \mathrm{~K}$ Compliance Certification.

\subsection{System Dates and Date Related Functions}

It is not completely known hiow system dates will be processed in the control system in the GEMS. One of the PLCs in the Allen Bradley SLC- $500^{\circledR}$ family will be used. A supplementary computer may be incorporated to provide the required capability to store a limited history. This computer may process dates and dated related functions.

\subsection{System Software for the GEMS}

The Seller is responsible for the providing the PLC software (ladder logic) and any other software that is necessary. The procurement specification requires software description documents, software verification and validation plans, and test report to be prepared for the PLC software and other system software (Bussell, 1998). The Seller may use third party software to develop the system software. In this case, the procurement specification requires that the seller provide $\mathrm{Y} 2 \mathrm{~K}$ certification from the third party.

\subsection{Year 2000 (Y2K) Compliance of the PLC}

Allen Bradley ${ }^{\circledR}$ claims that the SLC- $500^{\circledR}$ family of PLCs does not contain clocks. In other words, the SLC- $500^{\circledR}$ family of PLCs does not contain a real-time clock (RTC). Therefore, the product does not have any date-specific functionality and is not affected by changes in dates. Y2K compliance information was obtained from links contained on http://www. ab.com. The Allen Bradley ${ }^{\otimes}$ position is that the SLC- $500^{\circledR}$ family of PLCs does not contain real time clocks and therefore there is not $\mathrm{Y} 2 \mathrm{~K}$ issue

\subsection{Year 2000 (Y2K) Compliance of the Supplementary Computer}

It is unknown at this time whether the GEMS will have a supplementary computer in addition to the PLC. It is also unknown what type of computer the seller may use. We do not anticipate a Y2K compliance problem because of the requirements in the procurement specification. 


\subsection{Year 2000 (Y2K) Compliance of the Alpha and Beta CAMs}

The Eberline ALPHA6A ${ }^{\circledR}$ CAM and the Eberline AMS $4^{\circledR}$ CAM are Y2K compliant according to the manufacturer. Y2K compliance information on the Eberline AMS $4^{\circledR}$ or the Eberline ALPHA-6A ${ }^{\otimes}$ was obtained from Eberline Instruments' web site, http://umw.eberlineinst.com.

\subsection{Year 2000 (Y2K) Compliance of Miscellaneous Instrumentation} Miscellaneous instrumentation in the GEMS is provided by the Seller as described in the procurement specification (Bussell, 1998). It is expected that the miscellaneous instrumentation will not contain real-time clocks. Therefore, there should be no Y2K problems with these instruments. If smart instruments with real-time clocks are provided with the GEMS, the Seller is required to provide Y2K certification.

\subsection{Assessment of Potential Year 2000 (Y2K) Problems}

The schedule delivery date for the GEMS is during the fall of 1999. The GEMS will be installed during last part of 1999 to early part of 2000 . We do not anticipate a problem with $\mathrm{Y} 2 \mathrm{~K}$ problems because of the requirements contained in the procurement specification. We will require the Seller to include the required test suite in the "factory" acceptance test. The procurement specification requires that the "factory" acceptance plan to be approved by the Buyer.

\subsection{TEST PLAN}

The test plans for the Project W-420 will be contained in project acceptance test plans, operational test plans, and "factory" acceptance test plans.

\subsection{YEAR 2000 (Y2K) ACTIVITIES, MAJOR MILESTONES, AND DELIVERABLES}

Y2K activities, major milestones, and deliverables are contained within the project documentation. The primary $\mathrm{Y} 2 \mathrm{~K}$ activities are related to the procurement of the GEMS. Other Y2K activities, while not explicitly shown in project documentation, are contained in operational acceptance tests. 


\subsection{SCHEDULE}

Y2K activities for the GEMS are for most part contained within the GEMS procurement on the project schedule. Other $\mathrm{Y} 2 \mathrm{~K}$ activities are contained within operational acceptance tests.

\subsection{Key Project Documents}

Bussell, J.H., "Specification for Generic Effluent Monitoring System Procurement Specification," HNF-S-0400 REV. 1, 1998, Numatec Hanford Co., Richland, WA.

Carpenter, K.E., 1998, "Quality Assurance Plan for Project W-420," HNF-3285, REV. 0, Numatec Hanford Co., Richland, WA.

Carpenter, K.E., Renade, D.G., 1999, "Project W-420 Stack Monitoring System Upgrades (Project Execution Plan)," HNF-3011, REV. O, Numatec Hanford Co., Richland, WA.

Tuck, J.A., 1998a, "Project W-420 Stack Monitoring System Upgrades Conceptual Design Report," HNF-SD-W420-CDR-001, REV. 1, Numatec Hanford Co., Richland, WA.

Tuck, J.A., 1998b, "Functional Design Criteria for Project W-420 Stack Monitoring System Upgrades," HNF-SD-W420-FDC-001, REV. 1, Numatec Hanford Co., Richland, WA. 